ORIGINAL ARTICLE

\title{
Exploring revenge as a mediator between bullying and victimisation in gifted and talented students ${ }^{1}$
}

\author{
Hakan Sarıçam, Çă̆daş Çetinkaya \\ Dumlupinar University, Kütahya, Turkey
}

BACKGROUND

Gifted children are marked by their unique personal, emotional, and social needs and characteristics as well as their superior abilities. In this context, the aim of study was to explore the relationship between bullying, victimisation, and revenge in gifted students and explain whether or how they are effected by intellectual functioning and gender.

\section{PARTICIPANTS AND PROCEDURE}

Data was obtained from 318 (159 gifted, 159 non-gifted) volunteer secondary school students in Turkey. The Peer Bullying Scale Child Form and Vengeance Scale (VS) were used for data collection. While the data was being analysed, Pearson product moment correlation analysis, stepwise regression analysis, and Multivariate Analysis of Variance (MANOVA) were used because the data provided the criteria for parametric tests.

\section{RESULTS}

Research findings point out that there is a difference statistically between gifted and non-gifted students' peer bul- lying, victimisation, and revenge levels. Moreover, revenge was related positively to bullying victims in all students. Mediator revenge partially explains the relationship between victimisation and bullying. On the other hand, findings have shown that victim gifted children have higher revenge levels than do normal peers.

\section{CONCLUSIONS}

Bullying is highly connected with retaliation in the study of which children's opinions on effective strategies to cope with bullying are investigated; taking revenge is accepted as the best way to deal with bullying. Students who bully, their victims, and bystanders are all affected. Bullies can stress all of the people around them, creating a climate of fear and intimidation not only in their victims but also in their fellow students.

\section{KEY WORDS}

bullying; victimisation; revenge

CORRESPONDING AUthor - Hakan Sarıçam, Ph.D., Dumlupınar University Education Faculty, 43100 Kütahya, Turkey, e-mail: hakansaricam@gmail.com

AUthors' CONTRIBUtion - A: Study design - B: Data collection - C: Statistical analysis · D: Data interpretation . E: Manuscript preparation · F: Literature search · G: Funds collection

TO CITE THIS ARTICLE - Sarıçam, H., \& Çetinkaya, C. (2018). Exploring revenge as a mediator between bullying and victimisation in gifted and talented students. Current Issues in Personality Psychology, 6(2), 102-111.

RECEIVED 24.01.2017 · REVIEWED 20.03.2017 · ACCEPTED 21.07.2017 · PUBLISHED 18.12.2017 
Anybody can become angry - that is easy, but to be angry with the right person and to the right degree and at the right time and for the right purpose, and in the right way - that is not within everybody's power and is not easy.

Aristotle in about $310 \mathrm{BC}$.

\section{BACKGROUND}

In recent years, several educational initiatives have been taken in Turkey in order to keep up with worldclass standards in the field of special education. However, there is still a need to implement various reforms in the education for gifted/talented students, especially to cater for their social and emotional needs. Gifted and talented students are those children and youths who give evidence of higher performance capability in such areas as intellectual, creative, artistic, or leadership capacity, or in specific academic fields, and who require services or activities not ordinarily provided by the schools in order to develop such capabilities fully (Javits, 1988, p. 100-297).

It is safe to say that studies concerning giftedness in the domestic and global literature focus more on academic, positive, or promising traits of gifted and talented students. However, educators or parents having the propensity to concentrate gifted students' favourable aspects rather than negative ones are less likely to serve those students. Studies (Diezman \& Watters, 1997; Walsh, Hodge, Bowes, \& Kemp, 2010) attest that identifying and being aware of the negative and sensitive features of gifted students enable educators to supervise gifted/talented students more efficiently. In this study, therefore, two psychosocial factors - bullying/victimisation and revenge, which affect the educational experiences of gifted/ talented students, were elucidated.

\section{BULLYING AND VICTIMISATION}

Frequently-cited studies in literature were carried out by Dan Olweus, who asserts that an action ought to fulfil three criteria to be considered as bullying offensive deliberateness, repetition, and occurrence between unequal powers (Olweus, 1995). In recent years, several educational improvements have been accomplished in Turkey. The rationale behind these improvements was that Turkey needs to keep up with world-class standards in special education. To describe a behaviour as bullying, the behaviour has to be performed consciously by a powerful authority and be repeated over a period of time. Besides, Greene (2000) contributes to the literature by adding two characteristics of bullying: that the victim does not provoke bullying behaviour and bullying occurs in familiar social groups. "The bully" forces someone who is called "the victim" to do something they do not want to do (Frisen, Jonsson, \& Persson, 2007; Olweus, 1993; Unnever, 2005).

There are various sorts of bullying. For Olweus (1993), there are two types of bullying: direct (e.g. physical and verbal harassment) and indirect (e.g. social exclusion). Other researchers elaborate on bullying more specifically. For example, bullying is divided by Kochenderfer-Ladd (2002) into four types (physical, verbal, indirect verbal, and general), by Pearce (1997) into three (aggressive, anxious, and passive), and by Garrity Jens, Porter Sager, and Short-Camilli (2001) into five (physical aggressive, social alienation, verbal aggression, intimidation, and relational bullying) subgroups. Additionally, in Turkish literature, five types of bullying (physical, verbal, alienation, spreading rumours, and harming goods of others) are suggested, and Piskin and Ayas (2005) make a contribution to literature by adding sexual bullying to the five types. Another contemporary type of bullying is cyber or electronic bullying, which is seen mostly among adolescents mediated trough technology (Wang, Iannotti, \& Nansel, 2009).

The prevalence of bullying and victimisation among students in different levels and characteristics has been studied to a large extent. The ratio of victim students is $30.00-50.00 \%$ in Australia, $8.00-40.00 \%$ in Italy, $4.00-36.00 \%$ in England, $15.00-30.00 \%$ in Greece, $20.00-22.00 \%$ in Portugal, $21.00 \%$ in Canada, and $10.00 \%$ in the USA. Also, the ratio of bullying students is $20.00 \%$ in Italy and England, $6.00 \%$ in Greece, $12.00 \%$ in Canada, $13.00 \%$ in the USA, and $7.00 \%$ in Norway (Piskin, 2006, cited in Pişkin, M., \& Ayas, T., 2011). Although the prevalence of bullying/victimisation seems to be increasing in educational environments internationally, there is disagreement as to how bullying and its subtypes should be defined, and what methods for measuring such behaviour should be. As a result, precise rates of bullying/victimisation are hard to obtain (Espelage \& Swearer, 2003; Griffin \& Gross, 2004; Pelchar \& Bain, 2014). Griffin and Gross (2004) argue that studies carried out by diverse disciplines (e.g., sociology, psychology and education) should be incorporated to the relevant literature in order to help establish consensus about bullying and victimisation rates.

Bullying and victimisation are directly attributed to social preference and intellectual functioning of children. Children belonging to aggressive social groups are more included in bullying. Social isolation exerts a great impact on whether children are bullied (Peters \& Bain, 2011). Socially isolated children are more likely to be victimised than students in non-popular groups and popular groups. Since popular children seek to preserve their interpersonal strength, promote their social positions, and protect themselves by being excluded, they may bully others. On the other hand, peer and teacher nominations put children in different bullying orders in terms of 
their intellectual dispositions. Children with mild disabilities are rated by both their peers and teachers as utmost bullies. Gifted and non-gifted students are viewed as the worst bullies by their teachers and peers. In this sense, children with mild disabilities in the aggressive environment or popular group are the most inclined to perform bullying behaviour, whereas general education students in middle-peer groups are less likely to bully (Estell et al., 2008).

\section{REVENGE (VENGEANCE) AS MEDIATOR}

Revenge can be described as an act or affective process involving aggression in response to perceived aggression (Philips, 2003; Stuckless \& Goranson, 1992). Uysal and Satici (2014) claimed that revenge includes aggressive feelings against the individual who has performed injustice directly. What primarily motivates people to revenge are wishes for equality, justice, and reciprocity (Ferrari \& Emmons, 1994; Marongui \& Newman, 1987), teaching a subject morally and restoring a sense of self-worth (Yoshimura, 2007). Vengeful people are not only less forgiving, but also more likely to keep their motives against their offenders (McCullough, Bellah, Kilpatrick, \& Johnson, 2001). As far as execution of revenge is concerned, vengeful people are long-thinking, like ruminating about the event or the enemy, and prepare the revenge plan in detail (Barber, Maltby, \& Macaskill, 2005; McCullough et al., 2001). Revenge was positively associated with anger rumination (Satıc1, Can, \& Akın, 2015). As Conway, Csank, Holm, and Blake (2000) point out, rumination "consists of repetitive thoughts concerning one's present distress and the circumstances surrounding the sadness" (p. 404). Moreover, Sarıçam (2015) stressed that rumination and negative metacognitions have the same characteristic features. In this context, revenge may be a risk indicator for gifted students because their metacognition levels are higher than their non-gifted peers (Ogurlu \& Sarıçam, 2015). Revenge was negatively related to subjective well-being (Satıc1, 2016), psychological well-being (Bono, McCullough, \& Root, 2008; Ysseldyk, 2005), life satisfaction (McCullough et al., 2001), and psychological health (Ysseldyk, Matheson, \& Anisman, 2007), and positively related to antisocial behaviours (Stuckless \& Goranson, 1992) and aggressiveness (McCullough et al., 2001). Bullying is a type of aggression frequently seen among children and adolescents worldwide (Barcaccia, Schneider, Pallini, \& Baiocco, 2017; Shetgiri, 2013).

Bullying predicts later violence (Spivak \& Prothrow-Stith, 2001). One possible reason for revenge may be the desire for self-protection from future aggression or bullying. Victimisation is linked to peer rejection. Insensitivity of children to victimised peers can be considered as an indicator of dislike towards rejected peers. Rejection of peers depends on outcome expectancies and to what extent children appraise or value their peer, then rejected ones retaliate when attacked (Perry et al., 1990). Gifted children are vulnerable to traumatic victimisation by bullies, they may perform hypersensitive behaviours as a response to bullying (Peterson \& Ray, 2006). Many gifted school-age individuals are silent about their inner conflict (Peterson, 2001) and do not ask for help immediately (Peterson, 2002). Gifted victims of bullying may therefore suffer in silence, and educators and parents may not be aware of when a gifted child is being victimised. (Peterson \& Ray, 2006). Funches, Markley, and Davis (2009) found that retaliatory actions are sometimes motivated by revenge, and so they were used interchangeably in this study.

\section{PRESENT STUDY}

A vast portion of research on bullying and victimisation focuses on general school populations rather than gifted/talented students. Bullying and victimisation studies focusing on gifted/talented children can be based on two rudimentary understandings. First, gifted children are more vulnerable to being victimised than their other non-gifted peers and, second, is the opposite (Pelchar \& Bain, 2014). In vulnerability contrast comprehension, bullying and victimisation are directly attributed to social preference and intellectual functioning of children. Because gifted children are perceived as socially skilled, use effective social coping mechanisms, and are socially integrated with prosocial peers, they seem to be less threatened by social stressors (Estell et al., 2008). Reis, Neu, and McGuire (1997) suggest that many high-ability students who have learning disabilities may have negative school experiences. In fact, it is possible that gifted individuals who have a more sensitive structure than their peers with regard to regret, bullying, and vulnerability are likely to be impelled to social isolation by their peers (Davis, 2006). In addition, it is stated that external (e.g. aggressive behaviour) and internal (e.g. anxiety) factors were significantly correlated with bullying and victimisation (Garland \& Zigler, 1999). For this reason, it is natural to suspect that revengeful attitudes are somehow related to bullying and victimisation as an internal factor. However, no study elaborating on these psychological beings in regard to intellectual functioning and gender at the same time was encountered in the extant literature. In this context, we aimed to investigate whether a presumed theoretical path including bullying, victimisation, and revenge works in a sample of the gifted and how they are affected by cognitive superiority and gender. 


\section{PARTICIPANTS AND PROCEDURE}

Data was obtained from 318 (159 gifted/talented, 159 non-gifted) voluntary secondary school students in different cities in Turkey. Gifted/talented students were attending the Science and Art Centre (BILSEM) where there are places in which students who have IQ score above 130 and high level of performance in leadership, intelligence capacity, creativity, art, or specific academic areas than their peers are educated outside the school time (Special Education Legislation, 2012; as cited in Sari \& Öğülmüş, 2014) in Turkey, while their peers, who had average intelligence scores, abilities, and skills for science and art were enrolled in a public secondary school. Note that our sample consists of intellectually gifted children inasmuch as recruitment of children having other types of giftedness began in 2015 .

\section{MEASURES}

The Peer Bullying Scale Child Form, which was developed by Pişkin and Ayas (2011), was used to define bully and victim in bully behaviours among children. The scale is a self-report scale and it consists of 37 items, and two main parallel subscales - victim form (e.g. threatening "done me") and bully form (e.g. threatening "I did") with five sub-dimensions of each. First-order fit index CFA scores are $\chi^{2}=1422.14$ $(d f=616, p<.001), \chi^{2} / d f=2.30$ RMSEA $=.056$, $\mathrm{GFI}=.85$, AGFI $=.82$, CFI $=.92$, NFI $=.87$, and NNFI $=.91$. The model had acceptable second/ higher-order fit index values $\chi^{2}=1471.43(d f=621$, $p<.001), \chi^{2} / d f=2.36$, RMSEA $=.057$, GFI $=.84$, AGFI $=.82$, CFI $=.96$, NFI $=.87$, and NNFI $=.91$. The Cronbach $\alpha$ internal consistency of the scale was .90 for this sample. The reliability of "victim" subscale was calculated as .90 , and the reliability of "bully" subscale was calculated as .87 .

The Vengeance Scale, was originally developed by Stuckless and Goranson (1992) and adapted by Satıcı et al. (2015) into Turkish culture. The scale is a self-report and seven-point Likert type scale from 1 (strongly disagree) to 7 (strongly agree) and it consists of 20-items (e.g. "Revenge is morally wrong"). Confirmatory factor analysis scores demonstrated that the one-dimensional structure of the scale provided a good fit $\left(\chi^{2}=341, \chi^{2} / d f=2.23\right.$, NFI $=.95, \mathrm{CFI}=.97, \mathrm{IFI}=.97$, $\mathrm{RFI}=.94, \mathrm{GFI}=.91$, RMSEA $=.06$, and SRMR $=.05)$. It was also determined that the Cronbach's $\alpha$ internal consistency coefficient of the scale was $\alpha=.91$, while the test-retest correlation coefficient was $r=.87$.

\section{STATISTICAL ANALYSES (PROCEDURE)}

Participants in this study were voluntary, and data were collected during irregular class hours from the non-gifted students and gifted students in attendance. Data were collected from gifted/talented children, when they included in Gifted/Talented Children Education Programs (UYCEP). Participants were asked to fill out the Vengeance Scale and the Peer Bullying Scale Child Form. The completion of the instrument took approximately 25 minutes. The computer software analysis package program was used to perform statistical procedures. Data sets were purified from multivariate and univariate outliers so none of the participant were discarded from the set. Skewness and kurtosis coefficients and measures of central tendency were calculated and histograms were analysed so as to assess normality of bullying and victimisation and revenge scores. Since distribution coefficients remained in the \pm 1 acceptance range (Cohen, 1988), it was inferred that the data was fit for use in parametric tests. When the distribution histogram was examined, similar results were obtained. For this reason, it was decided to use parametric tests for forward analyses. The two-way MANOVA was conducted to find out the effects of gender and giftedness on bullying, victimisation, and revenge because the data provided criteria for two-way MANOVA. Pearson product moment correlation analysis was conducted to test the relation between revenge, bullying, and victimisation in gifted students; additionally, stepwise regression analysis was used for mediation analysis using Hayes' model templates for PROCESS (Model 4). The analyses were assessed by taking $95.00 \%$ confidence interval $p=.050$ as the criterion.

\section{RESULTS}

\section{GENDER AND MAJOR DIFFERENCES \\ IN VICTIMISATION, BULLYING, AND REVENGE SCORES}

The two-way MANOVA was conducted to explore if a significant variation exists in the scores of victimisation, bullying, and revenge by gender and giftedness. It is justified only when correlations exist among dependent variables (Fraenkel, Wallen, \& Hyun, 2012, p. 237), which is given above. Results are shown in Table 1 and Table 2.

Gifted students $(M=70.38, n=159, S D=25.43)$ scored higher than non-gifted peers $(M=62.84, n=159$, $S D=24.92)$ with respect to victimisation scores $(t=2.67, p<.010)$. Gifted students $(M=55.23$, $n=159, S D=22.06$ ) scored lower than non-gifted peers $(M=62.08, n=159, S D=23.56)$ with respect to bullying scores $(t=2.67, p<.010)$. Gifted students $(M=77.13$, $n=159, S D=24.77)$ scored higher than non-gifted peers $(M=70.09, n=159, S D=28.57)$ with respect to revenge scores $(t=2.35, p<.050)$. In addition, it was seen that mean scores of males were higher than females in all scales except gifted males in the revenge scale. 
Table 1

Descriptive statistics about victim, bully, and revenge levels according to gender and giftedness

\begin{tabular}{|c|c|c|c|c|c|c|}
\hline Variables & Student & Gender & $N$ & $\bar{x}$ & $S D$ & $t$ \\
\hline & & Female & 76 & 64.88 & 22.44 & $2.67^{* *}$ \\
\hline & Gifted & Male & 83 & 75.41 & 27.04 & \\
\hline & & Total & 159 & 70.38 & 25.43 & \\
\hline & & Female & 71 & 61.11 & 24.07 & \\
\hline \multirow[t]{9}{*}{ Victim } & Non-gifted & Male & 88 & 64.24 & 25.63 & \\
\hline & & Total & 159 & 62.84 & 24.92 & \\
\hline & & Female & 147 & 63.06 & 23.24 & \\
\hline & Total & Male & 171 & 69.66 & 26.84 & \\
\hline & & Total & 318 & 66.61 & 25.41 & \\
\hline & & Female & 76 & 52.67 & 17.80 & \\
\hline & Gifted & Male & 83 & 57.58 & 25.23 & \\
\hline & & Total & 159 & 55.23 & 22.06 & \\
\hline & & Female & 71 & 57.41 & 18.98 & \\
\hline \multirow[t]{9}{*}{ Bully } & Non-gifted & Male & 88 & 65.85 & 26.20 & $2.67^{* *}$ \\
\hline & & Total & 159 & 62.08 & 23.56 & \\
\hline & & Female & 147 & 54.96 & 18.47 & \\
\hline & Total & Male & 171 & 61.84 & 25.99 & \\
\hline & & Total & 318 & 58.66 & 23.05 & \\
\hline & & Female & 76 & 77.54 & 22.68 & \\
\hline & Gifted & Male & 83 & 76.76 & 26.67 & \\
\hline & & Total & 159 & 77.13 & 24.77 & \\
\hline & & Female & 71 & 69.11 & 24.58 & \\
\hline \multirow[t]{5}{*}{ Vengeance } & Non-gifted & Male & 88 & 70.89 & 31.55 & $2.35^{*}$ \\
\hline & & Total & 159 & 70.09 & 28.57 & \\
\hline & & Female & 147 & 73.4694 & 23.91 & \\
\hline & Total & Male & 171 & 73.7368 & 29.34 & \\
\hline & & Total & 318 & 73.6132 & 26.93 & \\
\hline
\end{tabular}

Note. ${ }^{* *} p<.01 .{ }^{*} p<.05$.

The results of two-way MANOVA and subsequent univariate analysis show that no interaction effect between gender and giftedness was observed. That is to say, the effect of giftedness or gender on our dependent variables shows high consistency and does not differentiate according to gender of participants or vice versa. However, significant differences were found for the main effect of giftedness (Wilks' $\Lambda=.886, F[3,159]=13.44$, $\left.p=.010, R^{2}=.04\right)$ on victimisation $(F[1,159]=7.08$, $\left.p=.010, \eta^{2}=.09\right)$, bullying $(F[1,159]=6.52, p=.010$, $\left.\eta^{2}=.07\right)$, and revenge $\left(F[1,159]=5.61, p=.010, \eta^{2}=.04\right)$. On the other hand, significant differences were found for the main effect of gender (Wilks' $\Lambda=.967, F[3,159]$ $\left.=3.52, p=.050, R^{2}=.04\right)$ on victimisation $(F[1,159]=$
5.91, $p=.050)$ and bullying $(F[1,159]=6.87, p=.010$, $\left.\eta^{2}=.08\right)$. However, it is impossible to mention statistically significant effect of gender on revenge $(F[1,159]$ $=.03, p>.050)$. These results indicate that gender or giftedness accounted for approximately $4-5.00 \%$ of the variance in victimisation, bullying, and revenge. Based on the $G^{*}$ Power guidelines, these were small effect sizes (Faul, Erdfelder, Buchner, \& Lang, 2013).

\section{MEDIATION ANALYSIS}

Pearson product moment correlation analysis was applied to scores of gifted students; Table 3 shows 
Table 2

MANOVA results of giftedness and gender effect

\begin{tabular}{|c|c|c|c|c|c|}
\hline \multirow[t]{2}{*}{ Variables } & \multirow[t]{2}{*}{ Wilks' $\Lambda$} & \multirow[t]{2}{*}{$F$} & \multicolumn{3}{|c|}{ Tests of between-subjects effects } \\
\hline & & & $\begin{array}{c}\text { Dependent } \\
\text { variables }\end{array}$ & Mean square & $F$ \\
\hline \multirow{3}{*}{ Giftedness } & \multirow{3}{*}{$.886^{* *}$} & \multirow{3}{*}{$13.44^{* *}$} & \multirow{3}{*}{$\begin{array}{l}\text { Victimisation } \\
\text { bullying } \\
\text { revenge }\end{array}$} & 4406.36 & $7.08^{* *}$ \\
\hline & & & & 3342.18 & $6.52^{*}$ \\
\hline & & & & 4036.68 & $5.61^{*}$ \\
\hline \multirow{3}{*}{ Gender } & \multirow{3}{*}{$.967^{*}$} & \multirow{3}{*}{$3.52^{*}$} & \multirow{3}{*}{$\begin{array}{l}\text { Victimisation } \\
\text { bullying } \\
\text { revenge }\end{array}$} & 3680.49 & $5.91^{*}$ \\
\hline & & & & 3518.98 & $6.87^{* *}$ \\
\hline & & & & 19.48 & .03 \\
\hline \multirow{3}{*}{ Giftedness ${ }^{*}$ Gender } & \multirow{3}{*}{.988} & \multirow{3}{*}{1.25} & \multirow{3}{*}{$\begin{array}{l}\text { Victimisation } \\
\text { bullying } \\
\text { revenge }\end{array}$} & 1081.67 & 1.74 \\
\hline & & & & 246.91 & .48 \\
\hline & & & & 128.79 & .18 \\
\hline
\end{tabular}

Note. ${ }^{*} p<.05 .{ }^{* *} p<.01$.

the inter-correlations of the variables, means, standard deviations, and internal consistency coefficients of the variables used.

Significant correlations among peer bullying, peer victimisation, and revenge scores were observed. It is seen that revenge scores produced, strong and small, respectively, significant correlation with bullying $(r=.63, p=.010)$ and victimisation scores $(r=.25$, $p=.010)$.

After the correlational prerequisite is seen to be met, the prediction of revenge by victimisation examined so as to test the verifiability that revenge may be the intervening variable between the independent variable (victimisation) and the dependent variable (bullying). It was verified that victimisation and revenge were positively related $(\beta=.25, t=3.26$, $p<.001)$. The results are shown in Table 4 .

For mediation procedure, two-stepwise multiple regression analysis was applied to assess which variables were the best predictors of bullying. Table 5 shows the results of stepwise regression analysis where the independent variables were victimisation and revenge levels, and the dependent variable was bullying. Victimisation was entered into the equation first, accounting for $38.00 \%$ of the bullying variance. Revenge was entered in the second step, accounting for an additional $18.00 \%$ of the bullying variance. This
Table 3

Descriptive statistics, alphas, and inter correlations of the variables

\begin{tabular}{lccc}
\hline Variables & 1 & 2 & 3 \\
\hline Victimisation & - & & \\
Bullying & $.62^{* *}$ & - & \\
Revenge & $.25^{* *}$ & $.63^{* *}$ & - \\
$\bar{X}$ & 70.38 & 55.23 & 77.13 \\
SD & 25.43 & 22.06 & 24.77 \\
Alpha & .88 & .86 & .77 \\
\hline Note. ${ }^{* *} p<.01$. & & &
\end{tabular}

means that victimisation and revenge explained $56 \%$ of the variance in predicting bullying.

The standardised beta coefficients indicated the relative influence of the variables in the last model with revenge (Figure 1). The results of the stepwise regression analysis demonstrated that victimisation was positively associated with bullying $(\beta=.62$, $t=9.87, p<.001)$. However, when victimisation and revenge were taken together into the regression analysis, the significance of the relationship between victimisation and bullying $(\beta=.51, t=9.28$,

Table 4

The regression results of the relationship between victimisation and revenge

\begin{tabular}{|c|c|c|c|c|c|c|c|}
\hline \multirow[t]{2}{*}{ Variable } & \multicolumn{2}{|c|}{$\begin{array}{c}\text { Non-standardised } \\
\text { coefficients }\end{array}$} & \multirow{2}{*}{$\begin{array}{c}\text { Standardised } \\
\text { coefficients }\end{array}$} & \multirow[t]{2}{*}{$t$} & \multirow[t]{2}{*}{$R$} & \multirow[t]{2}{*}{$R^{2}$} & \multirow[t]{2}{*}{$F$} \\
\hline & $B$ & $S E_{B}$ & & & & & \\
\hline Victimisation & .24 & .075 & .25 & $3.26^{*}$ & .25 & .06 & $10.63^{*}$ \\
\hline
\end{tabular}


Table 5

Mediation role of revenge in the relation between victimisation and bullying: stepwise regression analysis with dependent variable bullying

\begin{tabular}{|c|c|c|c|c|c|c|c|}
\hline \multirow[t]{2}{*}{ Variables } & \multicolumn{2}{|c|}{$\begin{array}{c}\text { Non-standardised } \\
\text { coefficients }\end{array}$} & \multirow{2}{*}{$\begin{array}{c}\begin{array}{c}\text { Standardised } \\
\text { coefficients }\end{array} \\
\beta\end{array}$} & \multirow[t]{2}{*}{$t$} & \multirow[t]{2}{*}{$R$} & \multirow[t]{2}{*}{$R^{2}$} & \multirow[t]{2}{*}{$F$} \\
\hline & $B$ & $S E_{B}$ & & & & & \\
\hline $\begin{array}{l}\text { Step } 1 \\
\text { Victimisation }\end{array}$ & .54 & .054 & .62 & $9.87^{*}$ & .62 & .38 & $97.50^{*}$ \\
\hline $\begin{array}{l}\text { Step2 } \\
\text { Victimisation }\end{array}$ & .44 & .048 & .51 & $9.28^{*}$ & .75 & .56 & $99.21^{*}$ \\
\hline Revenge & .39 & .049 & .43 & $7.91^{*}$ & & & \\
\hline
\end{tabular}

Note. ${ }^{*} p<.001$.

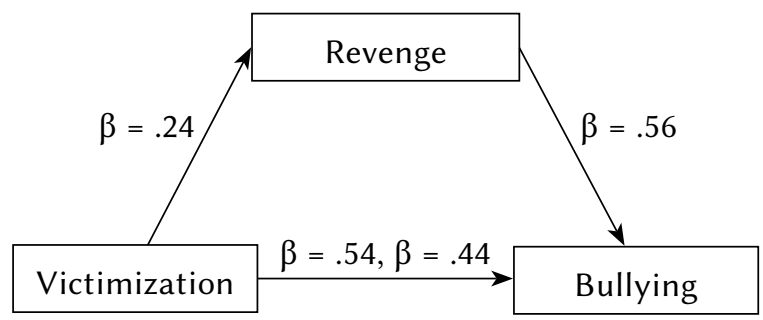

Figure 1. Mediator role of revenge.

$p<.001)$ decreased, but the relationship between victimisation and bullying was significant. According to Hayes (2013), this result indicated a partial mediation. Therefore, it can be said that revenge partially explains the relationship between victimisation and bullying.

The current model was tested using the Sobel z test, which aims at verifying whether a mediator significantly exerts the impact of an interdependent variable upon a dependent variable. The Sobel $\mathrm{z}$ test is characterised as being a restrictive test, and as such, assures that the verified results are not derived from collinearity issues (Sobel, 1982). In the current study, the test value verified was $Z=3.31444028, p=.00091827$.

At the end of the study, it was seen that revenge increased, if the victimisation levels increased in gifted children. This rise develops bullying. In other words, gifted children who are victims can take revenge easily, resulting in higher bullying.

\section{DISCUSSION}

In this study, we hypothesised that revenge can be an intervening element between victimisation and bullying, and also aimed to investigate whether or how giftedness and gender have an effect on bullying, victimisation, and revenge patterns of both gifted and non-gifted children. Accordingly, the study had both an exploratory and confirmatory nature by comparing two different groups. In the study, bullying or victimisation was accepted as a solitary structure, as well as revenge, thus the sub-categorical association of bullying and victimisation was not inspected. The study was primarily based on quantitative statistics; therefore, no causal relationship was investigated.

An important result of the study is that revenge partially mediates between bullying and victimisation. The central idea in this model is that effects of stimuli on behaviour are mediated by various transformation processes internal to the organism. Mediators explain how external physical events take on internal psychological significance (Baron \& Kenny, 1986, as cited in Hayes, 2009).

Another revelation of the study is that gifted students demonstrate greater ability to deal with, somehow, social stressors. The findings yield quite a subtle, relational path among dependent variables. According to the results, gifted children reported that they were more exposed to victimisation than their peers in general. It is conceivable and predictable that their desire for revenge may rise after being bullied; however, they choose relatively less often to indulge in violent behaviour. Since the likelihood of them resorting to any type of harassment or bullying remains lower other students, it led us to make various salient inferences.

The lower tendency of the gifted to avenge may originate from the fact that gifted children have a greater moral reasoning capability than other students. Gifted children are more likely to think that people do not deserve punishment or violence even if they are exposed to maltreatment by others. In other words, they are relatively matured not to appeal to reciprocal justice between sides of the coin (bully and victim). In spite of the fact that both violent and nonviolent children employ moral justifications beginning from early childhood (Smetana, Campione-Barr, \& Yell, 2003), they behave in opposite ways by concentrating on different aspects of transgression processes. Therefore, whereas violent children focus on retaliation, nonviolent ones prefer to adapt. Our findings remain on a partially confirmatory basis with the study of Camodeca and Goossens (2007). Berkowitz (1993) argued that vengeful people experi- 
ence more negative affect and are easily angered and offended by others. Students who bully, their victims, and bystanders are all affected. Bullying is highly connected with retaliation, as documented in studies where children's opinions on effective strategies to cope with bullying are investigated: taking revenge is accepted as the best way to deal with bullying. Bullies can stress all of the people around them, creating a climate of fear and intimidation not only for their victims but for their freinds as well (Bosworth et al., 1999). The partiality comes from a hypothetical structure that we construct among victimisation, revenge, and bullying revealing one-way relational paths. To be more precise, if we could predict victimisation by revenge or revenge by bullying, we could say whether the relational structure is corroborated by argumentation of Camodeca and Goossens (2007). The fact that gifted students in our study, who were less inclined to execute raging behaviours even if they thought that they were subjected to more victimisation, may eventually imply their social-emotional superiority.

Since no significant interaction influence between gender and giftedness has been observed in the study, it would not be possible to make inferences by considering these two variables simultaneously. Nonetheless, gender seems to be another factor that differentiates students' bullying and victimisation incidence and usually goes along with age and other independent variables like environmental factors, and educational and socioeconomic status. Peterson and Ray (2006), for example, speculated that students who have low assertiveness resulting from overprotective households and in low-socioeconomic background are more victimised. In addition, it is hard to indicate exact rates or prevalence of bullying and victimisation in any sample due to varying operational definitions of them. Griffin and Gross (2004) exemplify that when indirect forms of violence are comprised in measures, gender differences become insignificant. Also, Estell et al. (2009) stated that females have more contingency to engage in relational forms of bullying and males are more prone to physical forms of harassment. Although males appear to be more victimised and bullied in this study, we would not find value in going further and discussing gender issue in detail.

There are several limitations of the study, one of which is the standardisation sample issue of the Vengeance Scale that we used. The standardisation sample issue generically involved age differences between our study group and samples that were chosen by Stuckless and Goranson (1992). At this point, our main consideration would be of developmental variations across our study group and standardisation samples. There seems to be no reason to deny developmental differences of those who are in the eighth grade and undergraduate college students in many ways, especially in terms of social-emotional aspect. Although, for instance, empathetic competencies are positively correlated with age, this stance does not bring about a reduction in violence, and thereby victimisation. The propensity to be victimised of two developmentally different age groups may result in decisional difficulties. Another point that can be criticised is the language used in the original vengeance scale. Since it comprises intense idiomatic language, items may not be able to reflect what is attempted to be articulated. Next, revenge studies necessitate a long-term elaboration and observations to attain healthier results. Another restriction of the study is that the obtained data are all hypothetical self-report ratings that never happened. Data involved student self-reports, and corroborating data collected from other informants (e.g. teachers, parents, or other students) would have made the findings more robust. However, several studies have reported that bullying behaviours occur in locations (e.g. bathroom or school bus) and at times in which adult supervision is limited or non-existent (as cited in Bosworth et al., 1999). We have the foresight that when violence comes into reality, obtained paper-pencil results may become differentiate. To what extent these differences can be occurred is definitely open to further investigation.

Several recommendations can be made for further investigations. There is an obvious need for a tool which is compatible with and does not ignore primary school children's social-emotional development, so as to measure more healthily the vengeful postures of those children. After doing this, more precise results can be obtained. Additionally, although we have reached the conclusion that gifted children are well-qualified regarding emotional skills, it must be considered that our analyses were performed based on data from intellectually gifted and non-gifted students. Types of giftedness can have a determinant role in vulnerability, successive revenge, and bullying. For this reason, we strongly encourage examinations of violent and violent-reactive behavioural patterns of children who may have other types of giftedness (e.g. cultural intelligence).

\section{ACKNOWLEDGEMENT}

This research was partially supported by UYCEP. We thank our colleagues from UYCEP who provided insight and expertise that greatly assisted the research, although they may not agree with all of the interpretations/conclusions of this paper.

\section{ENDNOTES}

1 Some part of this study was presented as an oral presentation at $7^{\text {th }}$ International Congress on New Trends in Education 13-15 May 2016, Antalya, Turkey. 


\section{RefERENCES}

Barber, L., Maltby, J., \& Macaskill, A. (2005). Angry memories and thoughts of revenge: The relationship between forgiveness and anger rumination. Personality and Individual Differences, 39, 253-262. doi: 10.1016/j.paid.2005.01.006

Barcaccia, B., Schneider, B. H., Pallini, S., \& Baiocco, R. (2017). Bullying and the detrimental role of un-forgiveness in adolescents' wellbeing. Psicothema, 29, 217-222. doi: 10.7334/psicothema2016.251

Baron, R. M., \& Kenny, D. A. (1986). The moderatormediator variable distinction in social psychological research: Conceptual, strategic, and statistical considerations. Journal of personality and social psychology, 51, 1173-1181.

Berkowitz, L. (1993). Aggression: Its causes, consequences, and control. New York: McGraw-Hill Book Company.

Bono, G., McCullough, M. E., \& Root, L. M. (2008). Forgiveness, feeling connected to others, and well-being: Two longitudinal studies. Personality and Social Psychology Bulletin, 34, 182-195. doi: 10.1177/0146167207310025

Bosworth, K., Espelage, D. L., \& Simon, T. R. (1999). Factors associated with bullying behavior in middle school students. The journal of early adolescence, 19, 341-362. doi: 10.1177/0272431699019003003

Camodeca, M., \& Goossens, F. A. (2005). Children's opinions on effective strategies to cope with bullying: The importance of bullying role and perspective. Educational Research, 47, 93-105. doi: 10.1080/0013188042000337587

Cohen, J. (1988). Statistical power analysis for the behavioral sciences $\left(2^{\text {nd }}\right.$ ed.). Hillsdale, NJ: Erlbaum.

Conway, M., Csank, P. A. R., Holm, S. L., \& Blake, C. K. (2000). On assessing individual differences in rumination on sadness. Journal of Personality Assessment, 75, 404-425. doi: 10.1207/S15327752JPA7503_04

Davis, G. A. (2006). Gifted children, gifted education. A Handbook for Teachers and Parents. Great Potential Press Inc.

Diezmann, C. M., \& Watters, J. J. (1997). Bright but bored: Optimising the environment for gifted children. Australian Journal of Early Childhood, 22, 17-21.

Espelage, D. L., \& Swearer, S. M. (2003). Research on school bullying and victimization: What have we learned and where do we go from here? School Psychology Review, 32, 365-383.

Estell, D. B., Farmer, T. W., Irvin, M. J., Crowther, A., Akos, P., \& Boudah, D. J. (2009). Students with exceptionalities and the peer group context of bullying and victimization in late elementary school. Journal of Child and Family Studies, 18, 136-150. doi: 10.1007/s10826-008-9214-1

Faul, F., Erdfelder, E., Buchner, A., \& Lang, A.-G. (2013). G*Power Version 3.1.7 [computer soft- ware]. Uiversität Kiel, Germany. Retrieved from http://www.psycho.uni-duesseldorf.de/abteilungen/aap/gpower3/download-and-register

Ferrari, J. R., \& Emmons, R. A. (1994). Procrastination as revenge: Do people report using delays as a strategy for vengeance? Personality and Individual Differences, 17, 539-544. doi: 10.1016/01918869(94)90090-6

Fraenkel, J. R., \& Wallen, N. E. (1993). How to design and evaluate research in education. New York: McGraw-Hill.

Frisén, A., Jonsson, A. K., \& Persson, C. (2007). Adolescents' perception of bullying: Who is the victim? Who is the bully? What can be done to stop bullying? Adolescence, 42, 749-761.

Funches, V., Markley, M., \& Davis, L. (2009). Reprisal, retribution and requital: Investigating customer retaliation. Journal of Business Research, 62, 231238. doi: 10.1016/j.jbusres.2008.01.030

Garland, A. F., \& Zigler, E. (1999). Emotional and behavioral problems among highly intellectually gifted youth. Roeper Review, 22, 41-44. doi: 10.1080/02783199909553996

Garrity, C., Jens, K., Porter, W., Sager, N., \& Shatt-Camilli, C. (2001). Bully-proofing your school: A comprehensive approach for elementary schools ( $2^{\text {nd }} \mathrm{ed}$.). Longmont, Co.: Sporis West Educational Services.

Greene, M. B. (2000). Bullying and harassment in schools. In R. Scolaro Moser \& C. E. Frantz (Eds.), Shocking violence: Youth perpetrators and victims: A multidisciplinary perspective (pp. 72-101). Springfield: Charles C Thomas Pub Ltd.

Griffin, R. S., \& Gross, A. M. (2004). Childhood bullying: Current empirical findings and future directions for research. Aggression and Violent Behavior, 9, 379-400. doi: 10.1016/S1359-1789(03)00033-8

Hayes, A. F. (2009). Beyond Baron and Kenny: Statistical mediation analysis in the new millennium. Communication Monographs, 76, 408-420. doi: 10.1080/03637750903310360

Hayes, A. F. (2013). Introduction to mediation, moderation, and conditional process analysis: A regression-based approach. NY: Guilford Publications, Inc.

Javits, J. K. (1988). Gifted and talented students' education act (pp. 100-297). USA: Department of Education.

Kochenderfer-Ladd, B., \& Skinner, K. (2002). Children's coping strategies: Moderators of the effects of peer victimization? Developmental Psychology, 38, 267-278. doi: 10.1037//0012-1649.38.2.267

Marongiu, P., \& Newman, G. R. (1987). Vengeance: The fight against injustice. Tatowa, NJ: Rowman \& Littlefields.

McCullough, M. E., Bellah, C. G., Kilpatrick, S. D., \& Johnson, J. L. (2001). Vengefulness: Relationships with forgiveness, rumination, well-being, and the big five. Personality and Social Psychology Bulletin, 27, 601-610. doi: 10.1177/0146167201275008 
Ogurlu, U., \& Saricam, H. (2015). Metacognitive awareness and math anxiety in gifted students. Cypriot Journal of Educational Sciences, 10, 338348. doi: 10.18844/cjes.v10i4.228.

Olweus, D. (1995). Bullying at school: What we know and what we can do? Blackwell Publishers/AIDC.

Pearce, J. (1997). What can be done about the bully? In M. Elliott (Ed.), Bullying a Practical Guide to Coping in Schools (pp. 70-87). New Jersey: Pearson Education.

Pelchar, T. K., \& Bain, S. K. (2014). Bullying and victimization among gifted children in school-level transitions. Journal for the Education of the Gifted, 37, 319-336. doi: 10.1177/0162353214552566

Peters, M. P., \& Bain, S. K. (2011). Bullying and victimization rates among gifted and high-achieving students. Journal for the Education of the Gifted, 34, 624-643. doi: 10.1177/016235321103400405

Peterson, J. S. (2001). Gifted and at risk: Four longitudinal case studies. Roeper Review, 24, 31-39. doi: 10.1080/02783190109554123

Peterson, J. S. (2002). A longitudinal study of post-highschool development in gifted individuals at risk for poor educational outcomes. Journal of Secondary Gifted Education, 14, 6-18. doi: 10.4219/jsge-2002-384

Peterson, J. S., \& Ray, K. E. (2006). Bullying and the gifted: Victims, perpetrators, prevalence, and effects. Gifted Child Quarterly, 50, 148-168. doi: 10.1177/001698620605000206

Phillips, S. (2003). The social structure of vengeance: A test of black's model. Criminology, 41, 673-708. doi: 10.1111/j.1745-9125.2003.tb01001.x

Pişkin, M., \& Ayas, T. (2005). Lise öğrencileri arasında yaşanan akran zorbalığı olgusunun okul türü bakımından karşılaştırılması [Investigation of peer bullying among different type of high schools]. Paper presented at the 8th National Counseling and Guidance Congress. Istanbul: Marmara University (21-23 September 2005), Turkey.

Pişkin, M., \& Ayas, T. (2011). Akran Zorbalığı Ölçeği: Çocuk Formu [Peer Bullying Scale: Child Form]. Akademik Bakış Dergisi, 23, 1-12. Retrieved from http://www.akademikbakis.org/eskisite/23/07.pdf

Reis, S. M., Neu, T. W., \& McGuire, J. M. (1997). Case studies of high-ability students with learning disabilities who have achieved. Exceptional Children, 63, 463-479. doi: 10.1177/001440299706300403

Sarı, H., \& Öğülmüş, K. (2014). Evaluation of the problems faced by teachers and students in Science and Art Centers. Uluslararası Türk Eğitim Bilimleri Dergisi (UTEB), 2, 254-265.

Sarıçam, H. (2015). Metacognition and happiness: The mediating role of perceived stress. Studia Psychologica, 57, 271-283.

Satıcı, S. A. (2016). Forgiveness, vengeance, social connectedness and subjective well-being of university students: A study on examining different structur- al models. Unpublished PhD Thesis. Eskişehir: Anadolu University.

Satıcı, S. A., Can, G., \& Akın, A. (2015). The Vengeance Scale: Turkish adaptation study. Anatolian Journal of Psychiatry, 16, 36-43. doi: 10.5455/apd.170563

Shetgiri, R. (2013). Bullying and Victimization Among Children. Advances in Pediatrics, 60, 33-51. doi: 10.1016/j.yapd.2013.04.004

Smetana, J. G., Yell, N., \& Campione-Barr, N. (2003). Children's moral and affective judgments regarding provocation and retaliation. Merrill-Palmer Quarterly, 49, 209-236. Retrieved from http:// www.jstor.org/stable/23096228

Sobel, M. E. (1982). Asymptotic Confidence Intervals for Indirect Effects in Structural Equation Models. Sociological Methodology, 13, 290-312. doi: $10.2307 / 270723$

Spivak, H., \& Prothrow-Stith, D. (2001). The need to address bullying - an important component of violence prevention. Journal of the American Medical Association, 285, 2131-2132. doi: 10.1001/ jama.285.16.2131

Stuckless, N., \& Goranson, R. (1992). The Vengeance Scale: Development of a measure of attitudes toward revenge. Journal of Social Behavior and Personality, 7, 25-42.

Unnever, J. D. (2005). Bullies, aggressive victims, and victims: Are they distinct groups? Aggressive Behavior, 31, 153-171. doi: 10.1002/ab.20083

Uysal, R., \& Satici, S. A. (2014). The mediating and moderating role of subjective happiness in the relationship between vengeance and forgiveness. Educational Sciences: Theory \& Practice, 14, $2097-$ 2105. doi: 10.12738/estp.2014.6.2207

Walsh, R. L., Hodge, K. A., Bowes, J. M., \& Kemp, C. R. (2010). Same age, different page: Overcoming the barriers to catering for young gifted children in prior-to-school settings. International Journal of Early Childhood, 42, 43-58. doi: 10.1007/s13158010-0004-8

Wang, J., lannotti, R. J., \& Nansel, T. R. (2009). School bullying among adolescents in the United States: physical, verbal, relational, and cyber. Journal of Adolescent Health, 45, 368-375. doi: 10.1016/j. jadohealth.2009.03.021

Ysseldyk, R. L. (2005). Dispositions toward forgiveness and revenge in relation to coping styles and psychological well-being. Master thesis. Ottawa, Ontario: Carleton University.

Ysseldyk, R., Matheson, K., \& Anisman, H. (2007). Rumination: Bridging a gap between forgivingness, vengefulness, and psychological health. Personality and Individual Differences, 42, 1573-1584. doi: 10.1016/j.paid.2006.10.032

Yoshimura, S. (2007). Goals and emotional outcomes of revenge activities in interpersonal relationships. Journal of Social and Personal Relationships, 24, 87-98. doi: 10.1177/0265407507072592 